\title{
EDITORIALS
}

\section{The attitude of patients with mental disorders towards pharmacological and non-pharmacological treatments: emerging implications for clinical practice, service organization and research}

\author{
EDITORIALI \\ Il punto di vista dei pazienti con disturbi mentali nei confronti dei trattamenti \\ farmacologici e non farmacologici: implicazioni per la pratica clinica, \\ l'organizzazione dei servizi e la ricerca
}

\author{
CORRADO BARBUI, Guest Editor \\ and MICHELE TANSELLA, Editor
}

In recent years there has been a growing interest for exploring and describing the attitude of patients towards treatments provided by professionals working in mental health services. Not only the interest has been focused on whether patients perceive drug treatments as beneficial or harmful, but also on what patients think about non-pharmacological interventions, including psychological therapies and rehabilitative intervention programs provided by day-care centres, self-help groups or outpatient facilities. In the present issue of Epidemiologia e Psichiatria Sociale three Editorials discuss the current state of the art on this topic, and highlight the profound implications that the subjective attitude of patients may have in determining the long-term success or failure of comprehensive and articulated treatment plans.

A key aspect that clearly emerges from these three Editorials is a methodological question. How should the subjective attitude of patients towards a specific treatment program or a specific medicine be investigated? The three Editorials suggest that at least two distinct approaches may be followed, the first employs quantitative methodologies while the second is based on qualitative techniques.

The patients' subjective experience and well-being may be reliably rated by the patients themselves using standardised rating scales. During the last years rating scales have been developed to capture the attitude of patients towards the side-effects associated with antipsychotic treatment (Nosè, 2008) or their subjective wellbeing while receiving antipsychotic treatment (Naber, 2008). These scales have already been used in epidemiological and clinical studies that demonstrated that self-ratings by patients with severe mental disorders are possible,
Negli ultimi anni è progressivamente cresciuta la considerazione per il punto di vista soggettivo dei pazienti nei confronti dei trattamenti che vengono erogati dai servizi di salute mentale. Non solo l'interesse si è focalizzato sulla percezione della utilità dei trattamenti farmacologici, ma anche sulla percezione del significato e del senso di interventi psicologici, psicosociali e riabilitativi, e pure sul senso dei luoghi fisici della psichiatria, ovvero il reparto, l'ambulatorio, il centro di salute mentale, le strutture intermedie e ogni altro luogo del servizio psichiatrico. In questo numero di Epidemiologia e Psichiatria Sociale tre Editoriali discutono la letteratura esistente su questo argomento e le implicazioni che la percezione soggettiva dei pazienti viene inesorabilmente a determinare in termini di successo o fallimento dei programmi terapeutici, per quanto articolati e comprensivi questi possano essere.

Un aspetto centrale nel dibattito esistente su questi argomenti si riferisce ad aspetti di tipo metodologico. $\mathrm{Ci}$ si interroga su quali siano gli strumenti e i metodi più idonei per descrivere e misurare la percezione soggettiva dei pazienti nei confronti della utilità dei trattamenti. I tre Editoriali rispondono a questa questione proponendo due strade differenti: la prima presuppone l'uso degli strumenti e dei metodi delle ricerche quantitative, la seconda l'impiego di tecniche di tipo qualitativo.

Innanzitutto la soggettività dei pazienti può essere catturata utilizzando misurazioni effettuate dai pazienti stessi. Gli ultimi anni hanno, infatti, visto lo sviluppo di scale di valutazione standardizzate in grado di cogliere aspetti della soggettività dei pazienti sia in relazione alla percezione degli effetti collaterali degli antipsicotici (Nosè, 2008) che alla percezione di benessere inteso in senso più generale (Naber, 2008). Queste scale di valutazione sono state già 
useful and reliable (Naber, 2008). The Editorial by Naber highlights that a correlation between the patients' subjective experience and the degree of adherence to pharmacological treatments has already been shown, and this may have implications in terms of long-term patient outcomes. In addition to establish associations between epidemiological variables, this quantitative approach may help discover areas where the patients' subjective experience does not overlap with the health care providers' subjective experience. This is a compelling aspect that should probably receive more attention in clinical practice as well as in research activities: the Editorial by Nosè (2008) shows a substantial disagreement between patients and doctors in rating the troublesomeness of specific side effects, with patients often perceiving the side effects of antipsychotics at least as troublesome as the psychotic symptoms. In many cases, doctors were unaware of which particular side effects were perceived as more distressing. Clearly, this is expected to have implications in terms of doctor-patient relationship (Goss et al., 2007), therapeutic alliance and, consequently, adherence to treatment programs and drug regimens, especially in the long-term.

An added dimension in the evaluation of what patients perceive as helpful derives from qualitative research approaches. In contrast to quantitative methods, qualitative methods do not aim for reliability through the use of tools such as standardised questionnaires or through the use of randomly selected samples of patient populations. Qualitative methods usually aim for validity, by getting at how people really behave and what people actually think and believe about a specific issue. The Editorial by Davidson et al. (2008) is a bright example of this. Qualitative methodologies ("interviewing individuals") may be applied to the description of patient views on the utility of treatments, and very interesting results may be highlighted (Katsakou \& Priebe, 2007). In general, what patients describe as most helpful are relationships with others. If specific questions about antipsychotics are made, the key subjective experience is "a protracted process of trial and error through which people ended up finding first the right doctor or nurse, and then eventually the right medication. The "right" prescriber was someone who listened to the person, was willing to try different things, and who viewed the medication as more than just a way to reduce symptoms" (Davidson et al., 2008). This view exactly resembles the attitude that most of us have as patients dealing with personal health problems, that is "finding the right person first".

It is expected that in the next few years quantitative and qualitative methods will be increasingly adopted to pro- testate in studi epidemiologici e clinici che hanno dimostrato come l'autovalutazione di questi aspetti da parte dei pazienti sia possibile, utile e affidabile (sia in termini di attendibilità che di riproducibilità). L'Editoriale di Naber sottolinea in modo particolare la relazione esistente tra percezione soggettiva del beneficio dei trattamenti e adesione ai trattamenti stessi, nel senso che la percezione di basso beneficio inevitabilmente correla con bassi livelli di aderenza ai trattamenti. A loro volta, bassi livelli di aderenza ai trattamenti implicano esiti peggiori a lungo termine. Vi è poi un utilizzo iniziale di queste scale di misurazione orientato a studiare il grado di coerenza tra valutazioni effettuate dai pazienti e valutazioni effettuate dagli operatori sanitari. Si tratta di un aspetto di notevole interesse, che verisimilmente riceverà attenzione sempre maggiore in futuro. L'Editoriale di Nosè indica, secondo le ancora scarse valutazioni effettuate fino ad ora, un livello di disaccordo sostanziale tra queste due prospettive. I pazienti tendenzialmente pongono maggiore enfasi dei medici al carico esercitato dagli effetti collaterali dei trattamenti, mentre gli operatori spesso non sono nemmeno in grado di valutare quali effetti collaterali siano percepiti come particolarmente disturbanti dai loro pazienti. È chiaro che questa situazione verosimilmente ha un significato e un impatto sulla relazione tra medico e paziente (Goss et al., 2007), soprattutto in una prospettiva di presa in carico longitudinale che richiede, secondo la prospettiva del medico, un elevato grado di adesione ai programmi di cura.

Un approccio completamente differente per indagare e descrivere il medesimo fenomeno si fonda sull'impiego di metodi qualitativi. A differenza di quella quantitativa, la ricerca qualitativa non è interessata alla riproducibilità delle informazioni che genera, ma, in primo luogo, alla validità, ossia al fatto che ciò che si descrive corrisponda effettivamente a ciò che si intende descrivere. A questo fine, i metodi qualitativi si preoccupano di raccogliere informazioni su ciò che le persone pensano e su come le persone si comportano in risposta a determinati convincimenti. L'Editoriale di Davidson et al. (2008) fornisce un lucido esempio di come lavorano le metodologie qualitative e di come queste ultime siano in grado di rovesciare $\mathrm{i}$ punti di vista su questioni come, appunto, la percezione soggettiva dei trattamenti (anche rispetto agli approcci quantitativi dove gli strumenti di valutazione sono comunque sviluppati dagli operatori sanitari utilizzando inevitabilmente la loro prospettiva e non quella dei pazienti) (Katsakou \& Priebe, 2007). In linea generale, quando interrogati sulla utilità dei trattamenti, i pazienti intervistati dal gruppo di Davidson pongono l'accento sul valore terapeutico delle relazioni, sia in termini di relazioni con il personale sanitario, sia in termini più ampi, di relazioni 
vide complementary insights on these compelling issues. We ask qualitative methods to generate and develop ideas and concepts that may become research hypotheses to be formally tested by means of quantitative studies; in addition, findings from qualitative approaches may directly be applied by policy makers and health care professionals to the organization of community mental health services, where a therapeutic environment giving value to the crucial experiences of being accepted, understood and valued must be guaranteed. Similarly, we ask quantitative methods to better describe and quantify the relationship between subjective well-being, treatment acceptability and long-term outcomes; in addition, measures of subjective well-being need to be more often incorporated as outcome parameters in clinical trials investigating the beneficial and adverse effects of pharmacological and nonpharmacological treatments.

\section{REFERENCES}

Davidson L., Miller R. \& Flanagan E. (2008). What's in it for me? The utility of psychiatric treatments from the perspective of the person in recovery. Epidemiologia e Psichiatria Sociale 17, 177-181.

Goss C., Fontanesi S., Mazzi M.A., Del Piccolo L. \& Rimondini M. (2007). The assessment of patient involvement across consultation. The Italian version of the OPTION scale. Epidemiologia e Psichiatria Sociale 16, 339-349.

Katsakou C. \& Priebe S. (2007). Patient's experiences of involuntary hospital admission and treatment: a review of qualitative studies. Epidemiologia e Psichiatria Sociale 16, 172-178.

Naber D. (2008). Subjective effects of antipsychotic drugs and their relevance for compliance and remission. Epidemiologia e Psichiatria Sociale 17, 174-176.

Nosè M. (2008). Tolerability of antipsychotic drugs: does patient perspective deserve consideration? Epidemiologia e Psichiatria Sociale $17,182-185$ con altri pazienti per esempio, ma soprattutto con persone al di fuori del circuito assistenziale. Se gli intervistatori pongono l'accento sul valore dei trattamenti farmacologici, sul senso del trattamento con antipsicotici per esempio, i pazienti raccontano percorsi caratterizzati da numerosi tentativi di trovare innanzitutto "il medico giusto" e solo in un secondo momento "il farmaco giusto". Il medico giusto, nella prospettiva dei pazienti, è innanzitutto quello in grado di ascoltare, ed è in grado di porsi in una prospettiva più ampia e più ambiziosa rispetto all'obiettivo minimo di ridurre i sintomi della malattia. Se ci si pensa, questa percezione soggettiva è esattamente quella che ciascuno di noi ha nel momento in cui si trovi a dover gestire un problema di salute personale: il primo obiettivo, il più importante, è trovare la persona giusta a cui rivolgersi.

È verosimile che gli approcci quantitativi si integreranno sempre di più con quelli più tradizionali, quantitativi, al fine di portare contributi complementari su questioni così complesse e ricche di sfumature. $\mathrm{Ci}$ aspettiamo che la ricerca qualitativa generi idee e concetti innovativi che potrebbero divenire interessanti ipotesi di ricerca da testare utilizzando metodologie quantitative di tipo epidemiologico. Ci aspettiamo inoltre che alcuni concetti che emergono con insistenza dalle indagini qualitative vengano presi in considerazione e direttamente applicati alla pratica clinica quotidiana: la percezione di benessere che i pazienti mettono in relazione ad un contesto assistenziale accettante, che valorizzi le esperienze personali ponendo un forte accento alle dinamiche relazionali, non può non essere considerata una priorità all'interno e all' esterno dei luoghi entro cui l'assistenza psichiatrica si gioca. Allo stesso modo, ci aspettiamo che le metodologie quantitative descrivano con precisione sempre maggiore la relazione tra percezione soggettiva della utilità dei trattamenti, accettabilità dei trattamenti e esiti sul lungo periodo. Ci aspettiamo infine che la soggettività del paziente sia utilizzata sempre di più come variabile di esito nei trial clinici che valutano l'efficacia e la tollerabilità dei trattamenti farmacologici e non-farmacologici. 